\title{
Partial predation on tropical gorgonians by Cyphoma gibbosum (Gastropoda)
}

\author{
C. Drew Harvell ${ }^{1}$ \& Thomas H. Suchanek ${ }^{2}$ \\ ${ }^{1}$ Section of Ecology and Systematics, Cornell University, Ithaca, New York 14853, USA \\ ${ }^{2}$ Division of Environmental Studies, University of California, Davis, California 95616, USA \\ and \\ Bodega Marine Laboratory, PO Box 247, Bodega Bay, California 94923, USA
}

\begin{abstract}
Cyphoma gibbosum (Gastropoda, Ovulidae), a generalized predator on tropical gorgonians, forages selectively among gorgonian species on shallow reefs at St. Croix, U.S. Virgin Islands. Mean residence times of marked snails on prey taxa ranged from $1.8 \mathrm{~d}$ on Eunicea spp. to 4.7 and $10 \mathrm{~d}$ on Gorgonia ventalina and Plexaurella dichotoma respectively. Juveniles were sedentary and remained on single hosts throughout the study period. An analysis of wounds caused by C. gibbosum on gorgonians revealed that colonies of some taxa were consistently stripped of tissue, baring the underlying proteinaceous axis, while others were only superficially grazed. Wounds baring the axial skeleton were considerably more severe than superficial wounds because the bared skeleton could be colonized by algae causing subsequent tissue regeneration to be inhibited. Within all species, wounds were not restricted to any single portion of the colony. However, most wounds occurred within the central regions of colonies and the lowest portions of colonies were seldom damaged. The short residence times and superficial grazing on some taxa such as Eunicea spp. and Muricea spp. may be a consequence of heavy spicular armor over polyps and over the proteinaceous axis in those taxa. Deep wounds to the axial skeleton occurred only on taxa with smaller spicules and a smaller proportion of spicules in the coenenchyme by dry weight. Residence time on a prey species was inversely proportional to both maximum spicule length and percent composition of spicules. Short residence times and shallow wounds on colonies of heavily spiculed species may be a response by $C$. gibbosum to foraging on suboptimal, heavily defended resources. Despite the short residence times, these potentially suboptimal prey taxa were regularly visited and preyed upon. This suggests that factors other than spicular architecture, such as gorgonian chemistry, may also play a role in the foraging of C. gibbosum.
\end{abstract}

\section{INTRODUCTION}

Rather than killing their hosts and prey, many consumers such as herbivores, parasites, and grazers on colonies routinely remove only small quantities of tissue (Price 1980, Lubchenco \& Gaines 1981, Thompson 1982, Harvell 1984a, 1986). Partial predation (sensu Jackson \& Palumbi 1979, Harvell 1984a) is of particular theoretical interest because natural selection will operate differently on prey populations in which individuals typically survive encounters with predators. Attacks by non-lethal predators should favor inducible defenses and defenses that limit areal extent of damage (Harvell 1984 a, b, 1986, Rhoades 1985). Colonial invertebrates are only rarely killed by their predators and, due to their modular body plan and capacity for regeneration, may be little impaired by consumer attacks (Jackson \&
Palumbi 1979, Jackson 1983, Harvell 1984a, 1985). Understanding the interactions of partial predators with their prey is particularly important in tropical reef habitats where benthic communities are often dominated by reef-building colonial animals (Jackson 1983).

Although scleractinian and gorgonian corals (Cary 1918) dominate many benthic communities in the tropics, and gorgonian corals are known to be heavily invested with biologically active toxins (Coll et al. 1982, Fenical 1982, Gerhart 1983, 1984, Bakus et al. 1986), little is known of the patterns of attack by partial predators, or the consequences of attack and subsequent colony recovery. Types of attacks by corallivores are diverse and include tissue stripping (Birkeland \& Gregory 1975, Brawley \& Adey 1982, Glynn \& Wellington 1983, Wahle 1985), nipping of branch tips (Glynn et 
al. 1972, Neudecker 1979, Wellington 1982, Glynn \& Wellington 1983, Wahle 1985), and removal of individual polyps (Birkeland \& Neudecker 1981, Brawley \& Adey 1982, Lasker 1985). Most corals appear to recover readily from removal of individual polyps and damage to branch tips (Neudecker 1979, Wellington 1982, Wahle 1983a), but even minor amounts of tissue stripping can be catastrophic because fast-growing algae or Millepora spp. (Wahle 1980) can permanently colonize bared skeleton and prevent subsequent tissue regeneration (Wahle 1983a, 1985, Harvell \& Suchanek pers. obs.).

The effects of partial predation can be quantified as the proportion of an individual colony killed, but the functional role of lost units must also be considered since all parts of a colony do not function equivalently (Palumbi \& Jackson 1983, Harvell 1984a). Most colonies have ontogenetically based functional gradients; thus the consequences of an attack depend on its location and magnitude. For example, in some bryozoans, the central, oldest regions of a colony often cannot regenerate as rapidly as the outer perimeter (Palumbi \& Jackson 1983, Harvell 1984a). Attacks to the center of the colony may more often prevent colony recovery than attacks to the edge. Thus the consequences of damage to a colony are determined by both the location and scale of damage.

In this paper, we report on the interaction between a tissue-stripping tropical corallivore, Cyphoma gibbosum (Mollusca, Gastropoda) and its upright gorgonian prey. Although C. gibbosum feed exclusively on gorgonian corals, they can be considered trophic generalists because most available species in several gorgonian families are included in their diet (Birkeland \& Gregory 1975). C. gibbosum are ubiquitous throughout the Caribbean on shallow gorgonian-dominated reefs (Kinzie 1971, 1974, Birkeland \& Gregory 1975, Gerhart 1986). Two striking aspects of the interaction between C. gibbosum and its gorgonian prey are (1) the small amount of damage and low probability of mortality suffered by each attacked colony and (2) the great mobility of $C$. gibbosum while foraging among colonies (Birkeland \& Gregory 1975, Gerhart 1986). This is a common pattern for many predators attacking colonial invertebrates (Harvell pers. obs.) and may be, in part, a consequence of colony defenses (Gerhart 1986). The $C$. gibbosum-gorgonian interaction is a tractable system for analyzing intra-and inter-colony patterns of predator attack and colony defenses. We address the following 3 questions: (1) What are the intra-colony patterns of damage inflicted by $C$. gibbosum on the most heavily attacked taxa of gorgonians; (2) Do patterns of damage reflect underlying variations in colony function or morphology; and (3) What are the interspecific patterns of attack?

\section{METHODS AND RESULTS}

\author{
Study sites
}

All experimental work was conducted in St. Croix, U.S. Virgin Islands, during NULS-1 HYDROLAB mission 82-12 from 26 August to 21 September 1982. (See Suchanek 1983 for location map.) A shallow (4 to $10 \mathrm{~m}$ ) site was located on the gorgonian-dominated forereef with western exposure. The study site adjoined the deeper HYDROLAB site at Salt River Canyon. Samples for spicule analysis were collected in the forereef at Mama Rhoda Reef at Chub Cay in the northwestern Bahamas $\left(25^{\circ} 21^{\prime} \mathrm{N}, 77^{\circ} 52^{\prime} \mathrm{W}\right)$.

\section{Feeding selectivity}

Methods. Prey selection and residence times were quantified by marking all Cyphoma gibbosum and occupied gorgonians in the study area $\left(100 \mathrm{~m}^{2}\right)$ in St. Croix and recensusing the location of each snail daily. Each snail was uniquely marked by a system of 2 notches filed on the shell that coded for individuals from 1 to 80 . This was a minimally disruptive technique for marking large numbers of snails in situ: specimens were handled only briefly, and their appearance was generally unchanged. The behavior of marked individuals did not differ noticeably from the behavior of 5 individuals with natural distinctive marks that we monitored for the duration of the study (12 d).

The proportion of prey available was determined by recording the identity of every colony within the study area. Because it was impossible to reliably identify all the gorgonian species in the field, we lumped species into taxonomic and functional groups where necessary. We combined Plexaura flexuosa, P. homomalla, and Pseudoplexaura crucis into a Plexaura group, and lumped Muricea spp., Eunicea mammosa, and Eunicea spp. into a Eunicea group. The remaining genera and some species could be reliably distinguished on the basis of field characters.

A predator is considered to feed selectively when it takes any prey item in disproportionate numbers relative to its availability. A number of 'electivity indices' exist to analyze the discrepancy between the proportion of prey available and the proportion of prey attacked. A critical problem in the interpretation of some of these analyses is the way relative abundance affects the magnitude of the electivity index. For example, the Ivlev index weights electivities for rare prey disproportionately by dividing the difference between available and selected prey by the sum of the two. Because there is considerable variation in the behavior of different electivity indices, we applied 3 of the most widely used indices to the data: Ivlev's $\varepsilon$ (1961), 
Table 1. Cyphoma gibbosum. Comparison of different electivity indices calculated for snails foraging on gorgonians at St. Croix

\begin{tabular}{|c|c|c|c|c|c|}
\hline Taxon & $\begin{array}{c}\text { Proportion } \\
\text { available } \\
(\mathrm{N}=365)\end{array}$ & $\begin{array}{c}\text { Proportion } \\
\text { eaten } \\
(\mathrm{N}=149)\end{array}$ & $\begin{array}{c}\text { Chesson's } \\
\alpha\end{array}$ & $\begin{array}{l}\text { Ivlev's } \\
\varepsilon\end{array}$ & $\begin{array}{r}\text { Jacobs } \\
\log Q\end{array}$ \\
\hline Plexaurella dichotoma & 0.05 & 0.07 & 0.27 & 0.22 & 0.15 \\
\hline Eunicea group & 0.19 & 0.23 & $0.24(0.01)^{\bullet}$ & 0.09 & 0.10 \\
\hline Plexaura group & 0.62 & 0.66 & $0.21(0.01)^{\bullet}$ & 0.03 & 0.07 \\
\hline Briareum asbestinum & 0.01 & 0.01 & $0.19(0.02)^{\circ}$ & 0 & 0 \\
\hline Pseudopterogorgia americanum & 0.07 & 0.02 & $0.05(0.15)^{\bullet}$ & -0.55 & -0.57 \\
\hline Gorgonia ventalina & 0.05 & 0.01 & $0.03(0.81)^{\circ}$ & -0.70 & -0.87 \\
\hline
\end{tabular}

Chesson's $\alpha$ (1978), and Jacobs' log Q (1974). These were all developed for motile predators feeding on motile prey, but the extension to sessile prey does not violate any underlying assumptions. Electivity indices were calculated from the proportion of prey selected and the proportion of prey available. The proportion of prey selected was calculated by dividing the number of times a prey taxon was chosen by the total number of choices made.

To determine if Cyphoma gibbosum varied the duration of attacks on colonies of different species, we measured residence time: the number of days a snail remained on a prey colony. Residence times were only analyzed when the entire tenure of a snail on a colony was observed; individuals that stayed the entire study period on a single colony were assigned a residence time of $12 \mathrm{~d}$ for comparative analyses. Thus residence times in excess of $12 \mathrm{~d}$ will be underestimated by our observations. We monitored over 80 snails intensively to improve our estimates of residence time on the most abundant taxa.

Results. Table 1 summarizes the indices obtained using 3 different measures of electivity. There are 2 important features of this comparison to note: (1) the order (or 'preference' for the different prey items) does not change with different indices, giving us confidence in the relative ranking of preference for prey, (2) the range of values varies with the index used. Therefore, the rank order of preferences is relatively robust, while the absolute magnitude of scores for preferences is not. For our purposes, the ' $\alpha$ ' index (Chesson 1978) was most useful because (1) it varies continuously between 0 and 1 and is thus 'bounded' and (2) relative prey abundance affects the magnitude of the index so that selection of rare prey is detected, but the electivity for rare prey is not disproportionate. Our analysis failed to reject the null hypothesis that Cyphoma gibbosum attacked colonies in proportion to their relative abundance $\left(\chi^{2}, p>0.05\right)$ (Table 1$)$; therefore, we conclude that there is no active selection of prey colonies during the initial encounter phase of interactions.
Another measure of selectivity for a colony is residence time, which can vary independently of electivity. Residence times of adult Cyphoma gibbosum (Table 2) varied significantly among different prey groups (Plexaura, Eunicea, and Plexaurella) (Kruskall Wallis Test, $\chi^{2}=8.712, p<0.013$ ) where observations were numerous enough to permit analysis. A Median Test (Zar 1974) showed that residence time was significantly longer on the Plexaura group than on the Eunicea group ( $\left.\chi^{2}=7.95, \mathrm{p}<0.005\right)$. Increased sample sizes for rarer taxa, such as Pseudopterogorgia spp. and Gorgonia ventalina, would probably yield significantly longer residence times than for other taxa. Juvenile $C$. gibbosum do not move frequently among prey species; all juveniles remained on single hosts for the entire sample period (Table 2).

\section{Scar length, depth, and position}

Methods. For each of 6 taxa, Plexaurella dichotoma, the Plexaura group ( $P$. homomalla, Plexaura spp., $P$. nlexuosa, and Pseudoplexaura crucis), the Eunicea group, Pseudopterogorgia americanum, Pseudopterogorgia spp. (P. rigida and P. acerosa), Gorgonia ventali-

Table 2. Cyphoma gibbosum. Summary table of electivity and residence times (d) on different taxa of gorgonians

\begin{tabular}{|c|c|c|c|c|}
\hline \multirow[t]{2}{*}{ Taxon } & \multirow{2}{*}{$\begin{array}{c}\text { Electivity } \\
(\text { Chessons's } \alpha \text { ) }\end{array}$} & \multicolumn{3}{|c|}{ Residence time (d) } \\
\hline & & Mean & $S D$ & $(\mathrm{~N})$ \\
\hline Plexaurella dichotoma & 0.27 & 1.8 & 1.2 & (6) \\
\hline Eunicea group & 0.24 & 1.4 & 0.9 & (29) \\
\hline Plexaura group & 0.21 & 2.9 & 2.4 & $(50)$ \\
\hline Briareum asbestinum & 0.19 & 1.0 & 0 & (2) \\
\hline $\begin{array}{l}\text { Pseudopterogorgia } \\
\text { americanum }\end{array}$ & 0.05 & 4.7 & 4.1 & (3) \\
\hline Gorgonia ventalina & 0.03 & 10.0 & 0 & (2) \\
\hline All adults & & 3.3 & 3.4 & $(92)$ \\
\hline Juvenile $C$. gibbosum & & 12.0 & 0 & (9) \\
\hline
\end{tabular}



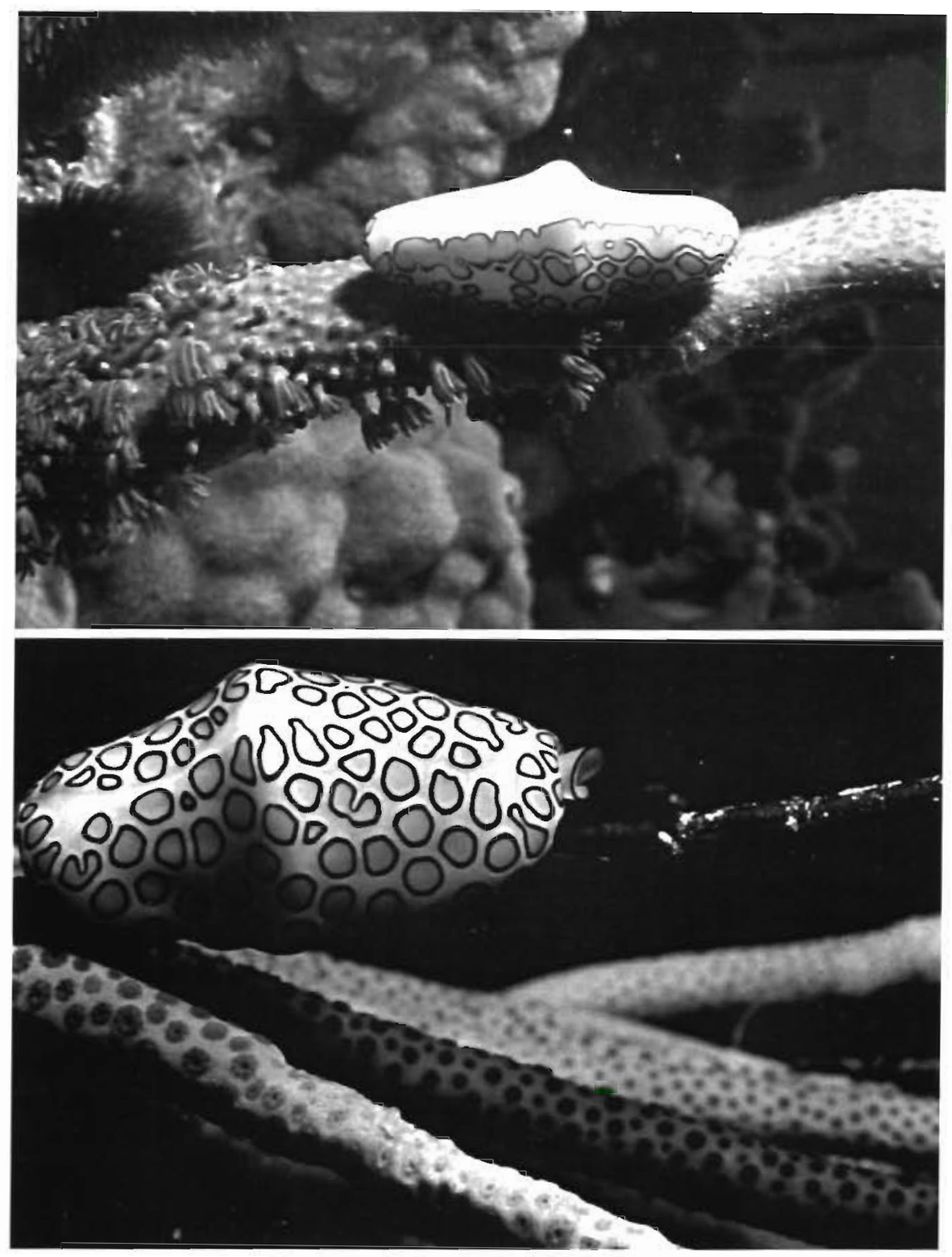

Fig. 1. (a) Cyphoma gibbosum feeding on Briareum asbestinum and causing only superficial damage. (b) C. gibbosum feeding on the gorgonian Plexaura spp. The deep feeding scar has exposed the underlying gorgonin skeleton na, and Briareum asbestinum, we measured the length of naturally occurring feeding scars (usually with a snail still present), the distance from the base of a colony to the base of a scar (here defined as the point of initiation), and the total height of each colony.

We scored the depth of naturally occurring feeding scars as either superficial or skeletal. Skeletal wounds completely bared the underlying gorgonin skeleton (Fig. 1). These categories were straightforward to distinguish and are functionally significant to the colony. For scars on Briareum asbestinum, a scleraxonian without a gorgonin skeleton, we classified skeletal wounds as those that exposed the innermost spicular layer. The frequency of individuals with skeletal scars in each taxon was compared over all taxa with a G-Test (Sokal \& Rohlf 1981).
Intra-colony locations of scars were examined to detect consistent locations of preferred attack. The height from colony base to scar initiation was divided by the total height of a colony to provide a normalized measure for comparison among species.

Results. Feeding scars were distributed throughout the middle regions of colonies on all species. In Fig. 2 we have plotted the point of scar initiation normalized by colony height. The $95 \%$ confidence intervals around the means are large. Scars were usually not initiated in the lower $20 \%$ of colonies, suggesting that basal regions are avoided. With the exception of Plexaurella dichotoma, on which feeding scars were initiated in a narrow band in the midsection of colonies, scars appeared to be initiated broadly throughout central regions of colonies. 


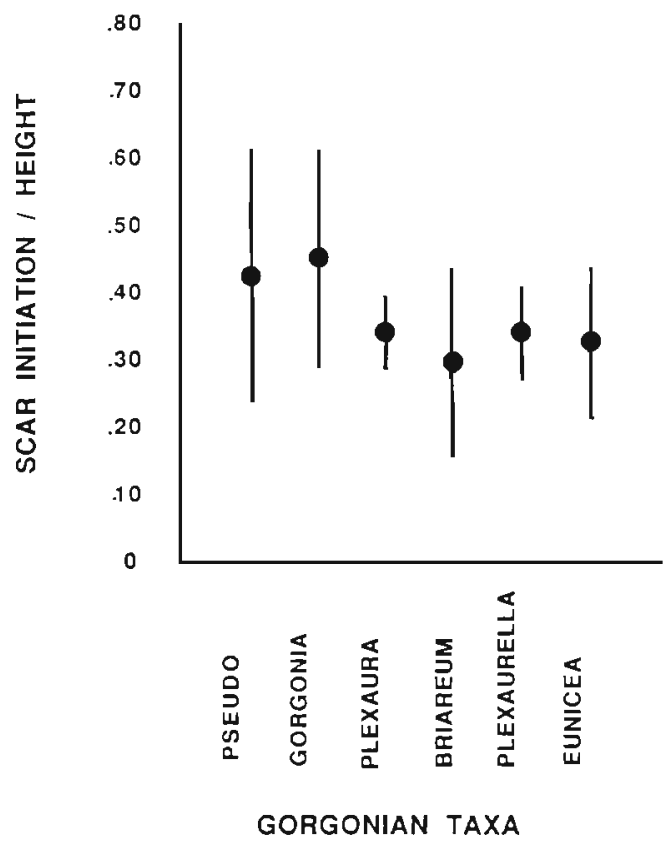

Fig. 2. Mean height of initiation of scars normalized by colony height (mean and $95 \%$ confidence intervals) on 6 taxa of gorgonians. Abbreviations for taxa are as follows: Pseudo: Pseudopterogorgia americanum; Gorgonia: Gorgonia ventalina; Plexaura: Plexaura group; Briareum: Briareum asbestinum; Plexaurella: Plexaurella dichotoma; Eunicea: Eunicea group

Scar lengths did not vary significantly among prey species (Table 3) and were not correlated with colony height (Pearson Product Moment correlation coefficient $p>0.05$ for all taxa).

Scar depth varied significantly among prey taxa $(G=$ 56.34, p <0.001; Table 3). Gorgonian taxa could be divided into 3 groups based upon the depth of wounds: (1) those that were usually $(>90 \%)$ wounded to the axis, including Pseudopterogorgia spp. and P. americanum; (2) those that were often (50 to $75 \%$ ) wounded to the axis, including Gorgonia ventalina, the Plexaura group, and Plexaura flexuosa; and (3) those that were rarely or never ( 0 to $15 \%$ ) wounded to the axis, includ- ing Plexaurella dichotoma, Briareum asbestinum, and the Eunicea group. Frequencies of skeletal wounding are not significantly different within each of the groups (G-Test, $p>0.05$ ), but are significantly different among groups (G-Test, $p<0.001$ ).

\section{Spicule size and composition}

Methods. Spicule size and percent composition in gorgonian colonies were analyzed to determine if maximum spicule size and percent composition of spicules were correlated with short residence times and superficial wounding. Spicule size was reported as the maximum spicule length given in Bayer (1961). The proportion of spicules was determined as the ash-free dry weight/total dry weight. Sections of gorgonian colonies, $3^{1 / 2} \mathrm{~cm}$ long, were collected at Chub Cay in the Bahamas and immediately preserved in $4 \%$ buffered formalin. Samples were soaked for $1 \mathrm{~h}$ in distilled water, the central gorgonin core removed, and the outer tissue dried at $60^{\circ} \mathrm{C}$ in a drying oven. After colonies were completely dry ( $1 \mathrm{~d}$ after they stopped losing weight), they were weighed and placed in a muffle furnace at $450^{\circ} \mathrm{C}$ for $4 \mathrm{~h}$. For this interval and temperature, only organic material should be combusted, and spicules should remain intact (Paine 1964). Above $500^{\circ} \mathrm{C}$, water of hydration may be separated from the calcium carbonate causing a further, confounding loss of weight (Paine 1964, Harvell pers. obs.). To be certain that calcium carbonate did not lose weight during this procedure, inorganic reagent-grade calcium carbonate was also processed with the gorgonian samples; there was no significant weight loss in 5 replicate samples processed.

Results. The dry weight composition of spicules varied significantly among taxa, ranging from approximately $35 \%$ for Pseudopterogorgia americanum to approximately $85 \%$ for Muricea spp. (Fig. 3). Four taxa stand out as having the highest percent composition of spicules: the Eunicea group, Plexaurella dichotoma, Plexaura flexuosa, and Muricea spp.

Table 3. Length $(\mathrm{cm})$ and depth of wounds caused by Cyphoma gibbosum on gorgonians. Wound depths were classified as skeletal or non-skeletal. Scar depth is reported as the percentage of skeletal wounds. -: no sample

\begin{tabular}{|c|c|c|c|c|c|}
\hline \multirow[t]{2}{*}{ Taxon } & \multicolumn{3}{|c|}{ Scar length } & \multicolumn{2}{|c|}{ Scar depth } \\
\hline & Mean & $\mathrm{SD}$ & $(\mathrm{N})$ & $\%$ & $(\mathrm{~N})$ \\
\hline Plexaurella dichotoma & 7.2 & 6.8 & (5) & 0 & (9) \\
\hline Eunicea group & 15.0 & 8.8 & (9) & 6 & (17) \\
\hline Briareum asbestinum & 13.4 & 7.7 & (7) & 14 & (8) \\
\hline Plexaura flexuosa & 11.9 & 10.5 & (9) & 62 & (8) \\
\hline Gorgonia ventalina & - & - & - & 50 & (6) \\
\hline Plexaura group & 12.0 & 7.9 & $(21)$ & 66 & (7) \\
\hline Pseudopterogorgia americanum & 11.7 & 8.1 & (10) & 95 & $(20)$ \\
\hline Pseudopterogorgia spp. & - & - & - & 100 & (10) \\
\hline
\end{tabular}


Maximum spicule length varied among taxa (Fig. 4) and with the exception of Plexaurella dichotoma, which has very small spicules, was generally proportional to percent composition of spicules (Pearson correlation coefficient $0.60, N=7$ ) (Fig. 4).

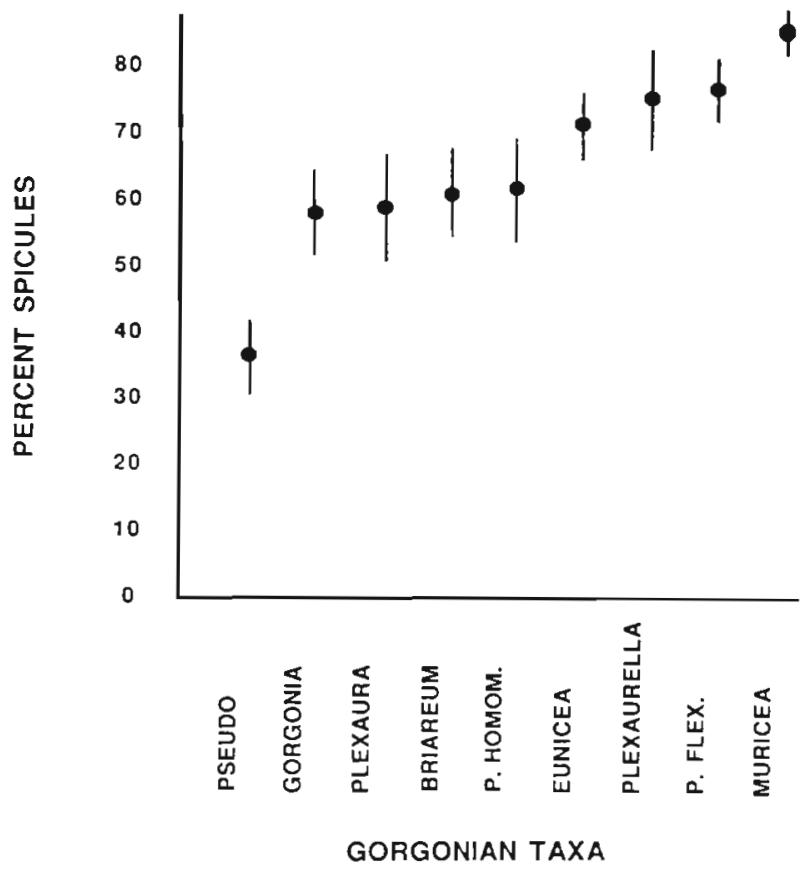

Fig. 3. Spicule composition of predominant prey taxa. Mean $(\mathrm{N}=4)$ and $95 \%$ confidence intervals are plotted. Taxonomic abbreviations as in Fig. 2, plus P. homom: Plexaura homomalla; P. flex.: Plexaura flexuosa; Muricea: Muricea spp.

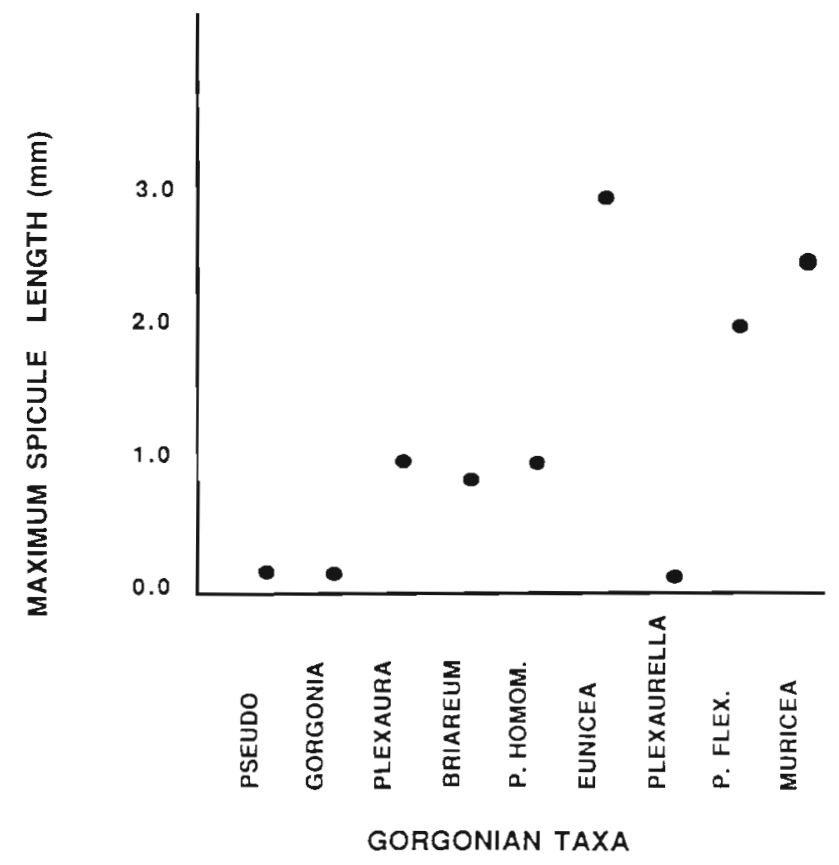

Fig. 4. Maximum spicule lengths of predominant prey taxa (lengths taken from Bayer 1961). Taxonomic abbreviations as in Fig. 2 \& 3

\section{DISCUSSION}

The extent of damage by Cyphoma gibbosum to gorgonian colonies varied among prey taxa. Only one species was consistently wounded to the skeleton (Pseudopterogorgia americanum), exposing it to invasion by colonizing algae. The depth of attack on gorgonian colonies appears to be determined by spicule size and architectural differences among prey taxa. Large spicules embedded in soft tissue or a high percent composition of spicules may act as a barrier to tissuestripping predators such as $C$. gibbosum. Thus taxa with small or a low composition of spicules may routinely suffer attacks from which recovery is inhibited.

In addition to the depth of the wound, the configuration of tissue loss also has major consequences for colony function. For example, in bryozoans, Harvell (1985) has shown that grazing by molluscs can accelerate reproduction of the entire colony. Wahle (1983b) has demonstrated that 'girdling' a colony of Plexaura homomalla can isolate and desynchronize the reproductive function of upper branches. Most attacks of Cyphoma gibbosum leave vertical scars not exceeding $1 \mathrm{~cm}$ in width (pers. obs.) and not girdling branches; thus branch tips are only occasionally isolated by $C$. gibbosum attacks. Within colonies, attacks were initiated predominantly in the middle and thus were less frequent on the lower $20 \%$ of colonies. The attack zone was broad enough on most taxa to suggest that there were no localized preferred sites within colonies.

Interspecific differences in prey quality appear to determine residence times of Cyphoma gibbosum, as well as the extent of damage to colonies. C. gibbosum spend significantly less time on heavily spiculed taxa such as Muricea spp., Eunicea spp., and Plexaurella dichotoma than on taxa from which they can extract more tissue $(r=-0.49$ [residence time with \% composition], $r=-0.63$ [residence time with spicule length]; $\mathrm{N}=7$ ). Thus, in addition to playing a role in colony architecture and support, spicules may also function as a defense against predators.

The observed distribution of Cyphoma gibbosum on gorgonians results from the interaction of both initial electivity and residence time. For comparison, we have recalculated Birkeland \& Gregory's data (1975) on electivity of foraging $C$. gibbosum for different gorgonian species (Table 1). They calculated electivity from censuses of $C$. gibbosum on marked gorgonians; thus their measure of electivity combines both the choices made by C. gibbosum among prey and the residence time on different prey. Their data show marked preference of C. gibbosum for Gorgonia ventalina, in complete contrast to our result of no significant electivity for any species. Because we followed the foraging choices of 
marked individuals, we were able to separate electivity from residence time. We found that while electivity for $G$. ventalina was not greater than that for other species, residence times were longest on $G$. ventalina. Thus it appears that $C$. gibbosum can attack prey in proportion to their relative abundance, yet still exercise selection among prey species by varying residence time. We predict that the foraging behavior of any partial predator can be divided into these 2 components, and that residence time may often be the more important variable in determining the observed patterns of prey selection.

Diet mixing has been invoked as an explanation for the generalized foraging tendencies of several predatory and herbivorous partial predators. Birkeland \& Gregory (1975), who also noted frequent movements of individual Cyphoma gibbosum among gorgonian prey species, concluded that $C$. gibbosum move often among prey to fulfill a diet-mixing requirement. Other corallivores also diet mix and maintain a wider diet breadth than expected from prey abundance alone. Birkeland \& Neudecker (1981) demonstrated diet mixing in the butterfly fish Chaetodon capistratus, which feeds on a range of scleractinian and gorgonian corals. Some herbivorous insects are known to forage widely to detoxify an otherwise unpalatable diet (Scriber 1984). There are several mechanisms by which the detoxification hypothesis may act: (1) compounds may interact so that combining feeding deterrents from different species may nullify the negative effects of certain compounds; (2) consumers may have an absolute tolerance for particular compounds that limits residence time on any one species, but allows mixing of different compounds (Berenbaum 1986). While our observations suggest that residence time is in part limited by spicule composition or architecture, the initial choice of prey taxa could be influenced by nutritive requirements based on past foraging history. We did note that individual C. gibbosum appear to switch prey taxa in successive attacks.

Another hypothesis to explain the short residence times of Cyphoma gibbosum on individual colonies is the inducible defense hypothesis suggested by Harvell (1984a). Colonies may respond to attacks with elevated levels of chemical defenses, in which case residence times of $C$. gibbosum could be limited by declining colony quality. Gerhart (1986) showed that residence times of $C$. gibbosum on previously attacked colonies of Plexaura homomalla are shorter than on previously unattacked colonies, thus providing some support for the inducible defense hypothesis.

Partial predation is a common pattern among most corallivores and other predators on colonies (Jackson 1983, Harvell 1984a, Buss 1986) as it is with herbivores (Thompson 1982). Birkeland \& Gregory (1975) calcu- lated that while a population of Cyphoma gibbosum may account for $62 \%$ of annual tissue loss to a population of gorgonians, they caused only $4 \%$ of the mortality. However, partial consumers may have dramatic sublethal effects on morphology and patterns of allocation to growth, reproduction, and defense within attacked colonies (Kaufman 1981, Wahle 1983b, 1986. Harvell 1984a, b, 1985, 1986). For example; one species of temperate bryozoan produces defensive spines (Yoshioka 1982, Harvell 1984a) and initiates reproduction (Harvell 1985) in response to attacks by partial predators. These temporally varying responses to predation may in turn decrease the quality of the prey and encourage consumers to reduce the duration of attacks. The short duration of most attacks by $C$. gibbosum could be a consequence of inducible structural or chemical defenses (Harvell 1984a, Gerhart 1986). Thus as in plants (Rhoades 1985), many colonies may have complex combinations of constitutive and inducible defenses which govern the foraging behaviors of their consumers

Acknowledgements. This research was supported in part by a NATO postdoctoral fellowship to C.D.H., NSF OCE8516407 to C.D.H. and R. T. Paine, NSF OCE8400818 to R. R. Strathmann, and NOAA NA-82-AAA-00872 and 01344 grants to T.H.S. L. Madin generously provided laboratory space for C.D.H. on a cruise to Chub Cay and at Woods Hole Oceanographic Institute. We are particularly grateful to $\mathrm{M}$. Colgan for cheerfully participating in long hours underwater at St. Croix and to $C$. Greene for assisting with collections in the Bahamas. This manuscript benefited from comments by $\mathrm{C}$. Greene, $\mathrm{M}$. Dethier, R. Strathmann, and 4 anonymous reviewers.

\section{LITERATURE CITED}

Bakus, G. J., Targett, N. M., Schulte, B. (1986). Chemical ecology of marine organisms: an overview. J. chem. Ecol. 12: 951-987

Bayer, F. M. (1961). The shallow water Octocorallia of the West Indian region. Studies on the Fauna of Curaçao and Other Caribbean Islands 12: 1-373

Berenbaum, M. (1986). Brementown revisited: allelochemical interactions in plants. Rec. Adv. Phytochem. 19: 139-169

Birkeland, C., Gregory, B. (1975). Foraging behavior and rates of feeding of the gastropod, Cyphoma gibbosum. Bull. Nat. Hist. Mus. Los Angeles Co. 20: 57-67

Birkeland, C., Neudecker, S. (1981). Foraging behavior of two Caribbean chaetodontids: Chaetodon capistratus and $C$. aculeatus. Copeia 1981: 169-178

Brawley, S. H., Adey, W. H. (1982). Coralliophila abbreviata: a significant corallivore. Bull. mar. Sci. 32: 595-599

Buss, L. W. (1986). Competition and community organization on hard surfaces in the sea. In: Case, T., Diamond, J. (ed.) Community structure. Harper and Row, New York, p. $517-537$

Cary, L. R. (1918). The Gorgonaceae as a factor in the formation of coral reefs. Carnegie Inst. Washington Pap. from the Tortugas Lab 9: 343-362

Chesson, J. (1978). Measuring preference in selective predation. Ecology 59: 211-215 
Coll, J. C., LaBarre, S., Sammarco, P. W., Williams, W T., Bakus, G. J. (1982). Chemical defences in soft corals (Coelenterata: Octocorallia) of the Great Barrier Reef: a study of comparative toxicities. Mar. Ecol. Prog. Ser 8: $271-278$

Fenical, W. (1982). Natural products chemistry in the marine environment. Science 215: 923--928

Gerhart, D. J. (1983). Chemical systematics of gorgonians. Biol. Bull. mar. biol. Lab., Woods Hole 164: 71

Gerhart, D. J. (1984). Prostaglandin $\mathrm{A}_{2}$ : an agent of chemical defense in the Caribbean gorgonian Plexaura homomalla. Mar. Ecol. Prog. Ser. 19: 181-187

Gerhart, D. J. (1986). Gregariousness in the gorgonian-eating gastropod Cyphoma gibbosum: tests of several possible causes. Mar. Ecol. Prog. Ser. 31: 255-263

Glynn, P. W., Stewarrt, R. H., McCosker, J. E. (1972). Pacific coral reefs of Panama: structure, distribution and predators. Sonderdruck aus der Geol. Rundsch. 61: 483-519

Glynn, P. W., Wellington, G. M. (1983). Corals and coral reefs of the Galapagos Islands. Univ. of California Press, Berkeley

Harvell, C. D. (1984a). Why nudibranchs are partial predators: intracolonial variation in bryozoan palatability. Ecology 65: 716-724

Harvell, C. D. (1984b). Predator-induced defense in a marine bryozoan. Science 224: 1357-1359

Harvell, C. D. (1985). Partial predation, inducible defenses and the population biology of a marine bryozoan (Membranipora membranacea). Ph.D. Dissertation, Univ. of Washington, Seattle

Harvell, C. D. (1986). The ecology and evolution of inducible defenses in a marine bryozoan: cues, costs, and consequences. Am. Nat. 128: 810-823

Ivlev, V. S. (1961). Experimental ecology of the feeding of fishes. Yale Univ. Press, New Haven, Connecticut

Jackson, J. B. C. (1983). Biological determinants of present and past sessile animal distributions. In: Tevesz, M. S., McCall P. L. (ed.) Biotic interactions in recent and fossi] benthic communities. Plenum Press, New York, p. 39-120

Jackson, J. B. C., Palumbi, S. R. (1979). Regeneration and partial predation in cryptic coral reef environments: preliminary experiments on sponges and ectoprocts. In: Levi, C., Bourg-Esnault. N. (ed.) Biologie des spongiaires. Centre National de la Recherche, Paris, p. 303-309

Jacobs, J. (1974). Quantitative measurement of food selection. A modification of the forage ratio and Ivlev's electivity index. Oecologia (Berl.) 14: 413-417

Kaufman, L. (1981). There was biological disturbance on Pleistocene coral reefs. Paleobiology 7: 527-532

Kinzie, R. A. (1971). The ecology of the gorgonians (Cnidaria, Octocorallia) of Discovery Bay, Jamaica. Ph.D. Dissertation, Yale Univ, New Haven, Connecticut

Kinzie, R. A. (1974). Plexaura homomalla: the biology of a harvestable marine resource. In: Weinhammer, A. J. (ed.)
Prostaglandins from Plexaura homomalla: ecology and utilization of a major medical marine resource. Univ. of Miami Press, Coral Gables, p. 22-38

Lasker, H. R. (1985). Prey preferences and browsing pressure of the butterflyfish Chaetodon capistratus on Caribbean gorgonians. Mar. Ecol. Prog. Ser. 21: 213-220

Lubchenco, J., Gaines, S. D. (1981). A unified approach to marine plant-herbivore interactions. A. Rev. Ecol. Syst. 12: 405-438

Neudecker, S. (1979). Effects of grazing and browsing fishes on the zonation of corals in Guam. Ecology 60: 666-672

Paine, R. T. (1964). Ash and calorie determinations of sponge and opisthobranch tissues. Ecology 45: 384-387

Palumbi, S. R., Jackson, J. B. C. (1983). Aging in modular organisms: ecology of zooid senescence in Steginoporella sp. (Bryozoa; Cheilostomata). Biol. Bull. mar. biol. Lab., Woods Hole 164: 267-278

Price, P. W. (1980). Evolutionary biology of parasites. Princeton Univ. Press, Princeton, New Jersey

Rhoades, D. F. (1985). Offensive-defensive interactions between herbivores and plants: their relevance in herbivore population dynamics and ecological theory. Am. Nat. 125: 205-238

Scriber, J. M. (1984). Host-plant suitability. In: Bell, W J., Carde, R. T. (ed.) Chemical ecology of insects. Sinauer, Sunderland, Massachusetts, p. 159-204

Sokal, R. R., Rohlf, F. J. (1981). Biometry. Freeman, San Francisco

Suchanek, T. H. (1983). Control of sea grass communities and sediment distribution by Callianassa (Crustacea, Thalassinidea) bioturbation. J. mar. Res. 41: 281-298

Thompson, J. (1982). Interaction and coevolution. Wiley Interscience, New York

Wahle, C. M. (1980). Detection, pursuit, and overgrowth of tropical gorgonians by milleporid hydrocorals: Perseus and Medusa revisited. Science 209: 689-691

Wahle, C. M. (1983a). Regeneration of injuries among Jamaican gorgonians: the roles of colony physiology and environment. Biol. Bull. mar. biol. Lab., Woods Hole 165: $778-790$

Wahle, C. M. (1983b). The role of age, size and injury in sexual reproduction among Jamaican gorgonians. Abstract. Am. Zool. 23: 961

Wahle, C. M. (1985). Habitat-related patterns of injury and mortality among Jamaican gorgonians. Bull. mar. Sci. 37 905-927

Wellington, G. M. (1982). Depth zonation of corals in the Gulf of Panama: control and facilitation by reef fishes. Ecol. Monogr. 52: 223-241

Yoshioka, P. M. (1982). Predator-induced polymorphism in the bryozoan Membranipora membranacea. J. exp. mar. Biol. Ecol. 61: 233-242

Zar, J. H. (1974). Biostatistical analysis. Prentice-Hall, Englewood Cliffs, New Jersey 